\title{
Synekdochy Wisławy Szymborskiej
}

\section{Abstract \\ Wisława Szymborska's Synecdoches}

The apothegms and lyric observations in the poetry of Wisława Szymborska have the nature of literal statements referring to the objective reality existing independently of the subject experiencing it. The literality understood in this way is a condition, and at the same time a consequence, of metaphorical transformation in numerous poems of Szymborska which use metonymy, synecdoche and antonomasia. Synecdoche, understood as part of a whole lending meaning to the whole, or the whole lending meaning to its part (according to Jerzy Ziomek) has the most prominence here - not only as a literary trope among other tropes within a poem, but also as an organizing principle of a poem as a whole, e.g. through frequent enumeration, characteristic of Szymborska. This constitutes a monistic image of the world, being a unity in plurality, in which enmity between different forms of being and territories of the world - people and animals, animals and plants, stones and thoughts, live and dead matter - is arbitrary and ideological, and - if specifically human, then in an ironic way.

Słowa kluczowe: poetycki obraz świata, monizm, dosłowność, sentencja, obserwacja liryczna, trop

Keywords: poetic vision of the world, monism, literality, apothegm, lyric observation, trope

Bezpośrednim impulsem do napisania tego artykułu stał się literacki koncept balladowego wiersza Wisławy Szymborskiej Jeszcze, który - tak jak wiele innych jej poetyckich kompozycji - polega na wielokrotnym wykorzystaniu tego samego chwytu. W świecie Jeszcze uwięzionych ludzi wszędzie czeka 
śmierć: wewnątrz zaplombowanych wagonów, na torach, w czarnym lesie, pośród innych. Sytuacja jest czytelna, ale zakomunikowana zostaje nie wprost: „przesłonięta” przez ciąg antonomazji. Dramat osób, ich cierpienie, ich bunt, ich konanie stają się dramatem imion. Nie osłabia to, przeciwnie, potęguje grozę bezradności. Trzy pierwsze strofy:

W zaplombowanych wagonach

jadą krajem imiona,

a dokąd tak jechać będą,

a czy kiedy wysiędą

nie pytajcie, nie powiem, nie wiem.

Imię Natan bije pięścią w ścianę,

imię Izaak śpiewa obłąkane,

imię Sara wody woła dla imienia Aaron,

które umiera $\mathrm{z}$ pragnienia.

Nie skacz w biegu, imię Dawida.

tyś jest imię skazujące na klęskę,

niedawane nikomu, bez domu,

do noszenia w tym kraju zbyt ciężkie ${ }^{1}$.

Fundamentalna w cytowanym utworze opozycja dosłowność-metaforyczność, stanowiąca rozróżnienie między przeciwstawnymi sposobami postrzegania świata ${ }^{2}$, nie była obca myśleniu poetki. Świadczy o tym jej inna ballada pt. Noc, w której pojawia się sformułowanie ,przeprowadzka z dosłowności do przenośni” (s. 25). Słowa te definiują moment rozstania z religią, ukazany jako zmiana miejsca obecności Boga, którą w dzieciństwie bohaterka przeżywa dosłownie, a u progu dorosłości - parabolicznie (kulturowo).

\section{Formy dosłowności}

W praktyce poetyckiej (nie tylko zajmującej nas autorki) poszczególne typy tropów różnią się między sobą odległościami od wypowiedzi dosłownych, operujących - jak to określał Kwintylian - słowem właściwym (verbum proprium $)^{3}$. Takie mianowicie tropy, jak porównanie, epitet metaforyczny, ironia czy alegoria, bywają nieraz mocno oddalone od dosłowności - aż do

1 W. Szymborska, Jeszcze [w:] eadem, Wiersze wybrane, wybór i układ Autorki, wydanie nowe, uzupełnione, Kraków 2010, s. 47. Przy kolejnych cytatach z tego źródła podaję w nawiasach numery stron.

2 Opozycja ta bywa kwestionowana przez teoretyków języka i literatury, nie tylko z kręgów postrukturalizmu, lecz także przez badaczy zaliczanych do polskiej szkoły semiotyczno-strukturalnej. Zob. A. Okopień-Sławińska, Metafora bez granic [w:] eadem, Semantyka wypowiedzi poetyckiej, Kraków 1998.

3 Zob. J. Ziomek, Retoryka opisowa, Wrocław 1990, s. 174. 
ostentacyjnego zerwania z nią więzi, kiedy to następuje słynne Peiperowe „samowolne spokrewnienie pojęć, któremu w rzeczywistości nic nie odpowiada", lub odbywa się postulowana przez Witolda Wirpszę, wyzwolona spod kontroli poznawczej, „gra znaczeń”. Z kolei inne tropy: metonimia, synekdocha i antonomazja uzyskują swe znaczenie w relacji do dosłowności. Zakładają jej potencjalną aktywność, gdyż to pamięć dosłowności stanowi conditio sine qua non ich ról w komunikacji werbalnej ${ }^{4}$.

Dosłowność w poezji Wisławy Szymborskiej uobecnia się pomiędzy sentencją a obserwacją, decydując zarówno o mowie, jak i o wymowie tekstowych całości. Sentencje, czyli całostki jedno- lub kilkuzdaniowe, w wielu jej wierszach przybierają postać definicji semantycznie samowystarczalnych, chciałoby się rzec: zamkniętych, zdolnych do samodzielnego funkcjonowania poza strukturą macierzystego utworu. W sensie logicznym i ontologicznym nie są to quasi-sady, lecz sądy pełnoprawne, komunikowane nam przez poetkę jako uniwersalnie prawdziwe. O zamierzonej asercji tych zdań świadczy ich filozoficzna zasadniczość, ustanawiana przez fundamentalne opozycje takich kategorii, jak: narodziny - śmierć, początek - koniec, jawa - sen, człowiecze - nieczłowiecze, bycie sobą - bycie „kimś całkiem innym” (s. 331). Swoiście definicyjny charakter zdań poświęconych kwestiom tak podstawowym jest w utworach Szymborskiej wzmacniany kategorycznymi sygnałami typu „każdy”, „wszechobecny”, „tylko”, „wszystko” „nic”, „nigdy”.

Sentencje, charakterystyczne dla języka filozofów starej daty (,staroświeckich jak przecinek" - s. 93), zajmujących się sporami o naturę rzeczy i istnienie świata, pojawiają się w dowolnych miejscach utworów Szymborskiej, nierzadko konstruowanych na wzór traktatu, eseju lub - najczęściej - felietonu (w stylu jej ,lektur nadobowiązkowych”). Na początku wiersza sentencje przybierają postać (hipo)tezy, otwierającej proces dowodowy, na przykład: „Nic darowane, wszystko pożyczone” (s. 318), „Na urodziny dziecka / świat nigdy nie jest gotowy” (s. 277), „Po każdej wojnie / ktoś musi posprzątać” (s. 294). Równie często znajdujemy je na końcu wiersza, w miejscu oczekiwanej pointy, wieńczącej - z reguły kapryśny, naładowany sprzecznościami i paradoksami - bieg rozumowania: „Każdy przecież początek, to tylko ciąg dalszy, a księga zdarzeń / zawsze otwarta w połowie” (s. 311), ,nie ma pytań pilniejszych / od pytań naiwnych” (s. 25), „Mogłam być sobą - ale bez dziwienia / a to by oznaczało, że kimś całkiem innym" (s. 331). I wreszcie, liczne poetyckie monologi wyposaża poetka - nazwijmy to tak - w pointy

4 Pogląd powyższy tylko pozornie przeczy tezom Okopień-Sławińskiej oraz cytowanych przez nią znawców, kwestionujących sens odróżniania podstawowego, dosłownego znaczenia pojedynczego wyrazu od mnogości jego znaczeń niedosłownych. Nie interesuje mnie tu bowiem pojedynczy wyraz, lecz fragment wypowiedzi poetyckiej, zorganizowany według reguł metonimii, synekdochy lub antonomazji, fragment postrzegany jako z a d a n i e dla czytelnika. O pojmowanej, ,zadaniowo", komunikacyjnej istocie artystycznego chwytu pisałem w artykule Perspektywy ,poetyki odbioru” [w:] Problemy socjologii literatury, red. J. Sławiński, Wrocław 1971. 
wewnątrztekstowe, rozrzucone w różnych miejscach wierszowej konstrukcji: „Zrodziliśmy się bez wprawy / i pomrzemy bez rutyny” (s. 28), „Tylko co ludzkie potrafi być prawdziwie obce” (s. 208), „Cud, tylko się rozejrzeć: / wszechobecny świat” (s. 284), „Bez nas snów by nie było” (s. 300).

O niektórych utworach Szymborskiej, zredukowanych do lirycznej miniatury, powiedzieć by można słowami Juliana Przybosia, że „składają się z samych point". Tak się dzieje w lapidarnych Trzech stowach najważniejszych:

Kiedy wymawiam słowo Przyszłość,

pierwsza sylaba odchodzi już do przeszłości.

Kiedy wymawiam słowo Cisza,

niszczę ją.

Kiedy wymawiam słowo Nic,

stwarzam coś, co nie mieści się w żadnym niebycie (s. 336).

Status takich wypowiedzi, formułujących myśli dobitnie i jasno, jest w poezji Szymborskiej dwojaki. Jeżeli są skierowane do wewnątrz świata poematu - uniemożliwiają racjonalną dyskusję, a zwłaszcza polemikę. Nie da się więc na przykład ani obalić, ani potwierdzić oznajmienia, że ,śni się żółwiowi listek sałaty” (s. 21), że czyjeś oczy „lśnią jak ryby w niebie” (s. 105), albo że „nieprzyjazd” bohaterki wiersza „do miasta N. / odbył się punktualnie” (s. 124). Tego rodzaju powiadomienia doskonale ilustrują teorię quasi-sądów Romana Ingardena. Jeżeli natomiast poetka odwołuje się do doświadczeń w świecie rzeczywistym - powszechnych, w równym stopniu dostępnych dla niej i dla jej czytelników, sytuacja zmienia się radykalnie. Gdy w wierszu Jawa czytamy: „Jawa nie pierzcha / jak pierzchają sny” (s. 300), nie tylko zdobywamy prawo, ale i lekturową powinność, wynikającą z natury sentencji, by zakwestionować lub potwierdzić trafność cytowanego (s)twierdzenia. Ktoś przytaknie, ktoś powie: jednemu nie pierzcha, a drugiemu pierzcha (gdy nagle traci przytomność). Ta rozmaitość reakcji czytelnika jest założona w strukturze sentencji jako całostki komunikacyjnej. Im dosłowniej sformułowane są sentencje, im mniej w nich polisemii tudzież metaforyczności, tym pewniej nawiązują dialogowy kontakt z czytelnikiem. Między innymi właśnie stąd - z tak urządzonej dosłowności złotych myśli w liryce Noblistki - wynika jej popularność 5 .

Jak wspomniałem, dosłowność wypowiedzi spełnia także inną funkcję, a mianowicie staje się $\mathrm{w}$ utworach poetyckich instrumentem i/lub materiałem obserwacji, która jest najbliższa opisowi o wzmożonej dynamice, kontrolo-

5 Malarka Zofia Pociłowska-Kann, wspominając swoje młodzieńcze zainteresowania filozofią i wynikające z tego przekonania, powiada: „Szymborska napisała, że o wszystkim decyduje przypadek, a mnie się wydaje, że działa każda z [...] trzech sfer", a mianowicie wolna wola, przypadek i przeznaczenie. Dotykanie życia. Z Zofia Pociłowska-Kann rozmawia Dariusz Zaborek, „Wysokie Obcasy”, dodatek do „Gazety Wyborczej” z 10 września 2016, nr 37, s. 14. 
wanemu przez obserwatorów, czyli zarówno przez ,ja” mówiące, jak i przez zaprojektowanego w tekście czytelnika.

Modalność tak zorganizowanej poetyckiej obserwacji określiłbym jako podjętą przez ,ja" liryczne próbę uzgodnienia z zaprojektowanym w wierszu czytelnikiem dwóch kwestii: (1) „czy dostrzegasz to samo, co ja?”, (2) „,czy zdarzają ci się spostrzeżenia oraz towarzyszące im emocje, podobne do tych, jakie ujawniam i analizuję?".

Pisałem przy innej okazji o ukrytych cyklach w poezji Szymborskiej, cyklach bez nazwy, bez tytułu, tworzących się w różnych tomikach poetki wskutek powrotu podobnych tematów, stylistyk czy konstrukcyjnych pomysłów na wiersz ${ }^{6}$. W tym kręgu da się wyróżnić ukryty c yk l obserwacj i lirycz$\mathrm{ny} \mathrm{ch}$. Obserwację liryczną jako swoisty gatunek charakteryzuje rytm dwudzielności, przywodzący na myśl szkolną charakterystykę sonetu, składającego się z części opisowej i refleksyjnej, przy czym w licznych obserwacjach lirycznych Szymborskiej opis i refleksja bywają z sobą splatane. W wierszu Chmury obserwacja ruchu ich zmiennych kształtów, wędrujących po zachmurzonym niebie, jest zarówno czynnością ,ja” podmiotu lirycznego, jak i przedmiotem jego (auto)refleksji. Analogicznie w takich kompozycjach poetyckich splatają się perspektywy poetyki autorskiej i poetyki odbioru. Szczególnym wariantem omawianego gatunku jest wiersz, w którym obserwator obserwuje obserwującego (Terrorysta, on patrzy). Podstawowy sens pisarskiego wysiłku określa tu nowość, nade wszystko zaś realistyczna celność zanotowanych spostrzeżeń, którą Przyboś (w odniesieniu do innej poetki, Marii Pawlikowskiej-Jasnorzewskiej) nazwał „ostrowidztwem obserwacji”7. Dzieje się tak m.in. w wierszach Mała dziewczynka ściaga obrus, Wypadek drogowy, Dom wielkiego człowieka... O tym, jak ważna jest celność spostrzeżeń budujących wiersz, świadczą sporadyczne wyrazy niezadowolenia, które odnoszą się do miernych rezultatów obserwacji, spowodowanych już to zagubieniem obserwatora w nadmiarze widoków ,świata ze wszystkich stron świata"'(s. 180), już to wadliwą pracą pamięci (Dzień 16 maja 1973 roku).

Wspólne założenia dla wszystkich wariantów dosłowności w poezji Szymborskiej są następujące:

Po pierwsze, zarówno sentencja, jak i obserwacja liryczna zbliżają język wiersza do polszczyzny użytkowej. W licznych partiach Chmur prawda o ich wyglądach zostaje wyłożona polszczyzną potoczną i jednoznaczną. Czytając, że chmury „Już po ułamku chwili / przestają być te, zaczynają być inne”, że „Ich właściwością jest / nie powtarzać się nigdy / w kształtach, odcieniach, pozach i układzie", i wreszcie, że ,natychmiast rozwiewają się na wszystkie strony" (s. 332), obcujemy w gruncie rzeczy z paraliteracką prozą, znaną z lekcji, z turystycznych przewodników, z mowy praktycznej, z językowej codzienności, służącej elementarnej orientacji w świecie.

6 E. Balcerzan, Pochwała poezji. Z pamięci, z lektury, Mikołów 2013, s. 260-261.

7 J. Przyboś, Linia i gwar, Kraków 1959, t. 2, s. 119. 
Po drugie, w wierszach poddanych regułom sentencji lub obserwacji lirycznej przyjmuje się założenie, że kształt obserwowanej realności - w chwili obserwacji - nie jest zależny od obserwatora. Niepostrzegany - byłby taki sam. W realności suwerennej, opornej wobec kulturowych czy ideologicznych uzależnień, ukazują się „lustra, które pracują gorliwie, / nawet gdy nikt nie patrzy” (s. 347), bytują chmury, które „Nie muszą być widziane, żeby z nami płynąć" (s. 332) etc.

I po trzecie, pożądana celność poetyckiej obserwacji zależy od talentu obserwatora i jego inwencji, lecz równocześnie wymaga pokory w podporządkowaniu się potencjalnym dyrektywom obserwowanej realności. Jeżeli obserwacja ujawnia wielość stanów czy procesów, to nie dlatego, że tak sobie życzy poeta, lecz dlatego, że w naturalną zawiłość zjawisk obfituje dostępny nam świat. Tę postawę ujmuje expressis verbis zwierzenie Profesora, podmiotu-bohatera wiersza Szymborskiej:

Kiedy wieczór pogodny, obserwuję niebo.

Nie mogę się nadziwić,

ile tam punktów widzenia (s. 379).

„Tam”, na zewnątrz, poza ludzką świadomością.

\section{Między dosłownością a przenośnią}

Źródłem synekdochy w ujęciu klasycznej retoryki jest rozumowanie $a$ fortiori („tym bardziej”) - mające na celu wzmocnienie tego, co dałoby się powiedzieć dosłownie, ale powiedziane synekdochą - powinno zostać odebrane jako tym bardziej udatne, obdarzone tym mocniejszą racją. Stąd wniosek, że mechanizm synekdochy, rozpatrywany w planie poetyki odbioru, polega nie tylko na substytucji wyrazów, lecz także na rozpoznaniu źródła substyt u c j i, co znaczy, że słowo właściwe, zastąpione w danym tekście przez inny wyraz, choć nie pojawia się w tekście, to jednak nie zostaje wyeliminowane ze świadomości odbiorcy, przeciwnie - musi być przez odbiorcę pomyślane jako utajone w porządku równoległym. Zdanie-obraz poetycki: „wentylatory mieszały żywioł upalny i chłodny” (s. 9), rozpoznane jako synekdocha w wariancie totum pro parte, musi zostać le k s y ka ln i e podwoj o n e. Czytamy „żywioł”, myślimy zarówno „żywioł”, jak i „powietrze”. Oba człony, jawny i ukryty, pozostają aktywne. Synekdocha przypomina zagadkę, ale w tej zagadce nie ma mylnych wskazówek, odwróconych zależności czy prób zdezorientowania odbiorcy. „Metonimia z synekdochą są to takie wyrażenia, w których między rematem a tematem zachodzi realny związek 
inkluzji (wzajemnego zawierania się w sobie) lub przyległości"». Mowa o realności postrzeganej inaczej niż w wypowiedziach dosłownych, jak sentencje czy obserwacje liryczne Szymborskiej. Jak próbowałem wykazać, w komunikacji nastawionej na dosłowność - realności przypisuje się stuprocentową niezależność od obserwatora i jego uwarunkowań kulturowych, światopoglądowych, ideologicznych, pragmatycznych etc., czyli - nie zauważa się determinant wynikających z osobliwości języka naturalnego oraz jego subkodów, z aktualnego stanu wiedzy, z wychowania i innych czynników determinujących poznanie. Operacje retoryczne, wykorzystujące mechanizmy metonimii, synekdochy lub antonomazji - odwrotnie - już to „czerpią swe uzasadnienia z pozajęzykowych, cywilizacyjno-kulturowych urządzeń świata", już to, by rozszerzyć myśl Ziomka, opierają się w sposób jawny na języku właśnie, zwłaszcza jego stereotypach utrwalonych we frazeologii.

\section{Między metonimią a synekdochą}

Retoryczne funkcje synekdoch oraz metonimii, charakterystyczne dla komunikacji praktycznej, rozpoznajemy w języku artystycznym liryki, ale i, co bodaj ważniejsze, stajemy się świadkami ich przetworzenia. Tu w rzeczy samej - by odwołać się do noblowskiego odczytu poetki - „nic już zwyczajne i normalne nie jest" (s. 408). A nie jest z tego powodu, że niektóre cechy zajmujących nas operacji komunikacyjnych, zauważane co prawda w retoryce polszczyzny użytkowej, lecz traktowane jako sporadyczne, drugorzędne bądź całkowicie nieistotne, a niekiedy wręcz kłopotliwe, okazują się w budowie tekstów poetyckich - najważniejsze ${ }^{10}$. Odnosi się to do różnic między metonimią a synekdochą, a w istocie do częstego bagatelizowania owych różnic w retorykach językoznawczych. Synekdocha jest tu traktowana jako wariant metonimii - w gruncie rzeczy - dość prowizoryczny. W rezultacie metonimiczna zasada przyległości „liniowych” porządków świata i synekdochiczna reguła zastępowalności fragmentu przez zbiór lub zbioru przez fragment by-

8 Ibidem, s. 175. Nieco wcześniej w cytowanej pracy czytamy: ,Już Kwintylian podkreślał w metonimii, polegającej na takim zastąpieniu «słowa właściwego» (verbum proprium) innym słowem, takim jednakże, którego znaczenie związane jest realnie ze słowem właściwym" (s. 174).

9 Ibidem, s. 178.

${ }^{10} \mathrm{Z}$ analogicznym odwróceniem hierarchii cech językowych, kiedy to „ostatnie” stają się ,pierwszymi”, mamy do czynienia w dziejach systemów wierszowych: tu elementami konstytutywnymi okazują się zjawiska przypadkowe i sporadyczne w językowej praktyce, takie jak powtarzalność sekwencji intonacyjno-rytmicznych lub współbrzmienie wyrazów. 
wają utożsamiane ${ }^{11}$, antonomazję traktuje się raz jako odmianę metonimii ${ }^{12}$, a kiedy indziej jako postać synekdochy ${ }^{13}$; wynika to z przekonania, wyrażonego dobitnie przez Jerzego Ziomka, że „nieraz jest rzeczą drugorzędną, czy zbiór [z którego wybieramy reprezentatywny detal - E.B.] zbudowany jest liniowo (przyległość), czy piętrowo (przyporządkowanie, inkluzja)"14.

Cytowaną refleksję można rozumieć w ten sposób, że nierzadko ten sam fragment tekstu, a co za tym idzie - fragment rzeczywistości przedstawionej $\mathrm{w}$ wierszu, mamy prawo interpretować na dwa sposoby: w planie metonimii albo w planie synekdochy.

Nasze jedyne spotkania po latach

to rozmowa dwóch krzeseł

przy zimnych stolikach (s. 345).

Jeżeli powiemy, że za wyrażeniem „rozmowa dwóch krzeseł” kryje się domyślne wyrażenie „rozmowa dwóch osób” czy „rozmowa dwojga ludzi”, to uznamy, że doszło tu do zamiany znaków w „liniowym” planie metonimii, czytelnej ze względu na fakt oczywistej, fizycznej bliskości ludzi i mebli (tu zapewne w kawiarni, restauracji, poczekalni, hotelowym holu etc.). Nie ma jednak zasadniczych przeszkód do rozpoznania w analizowanym fragmencie redukowania zbioru słów „rozmowa dwojga ludzi siedzących na krzesłach przy zimnych stolikach” do fragmentu „rozmowa dwóch krzeseł przy zimnych stolikach". W tym ujęciu tekst udostępniony odbiorcy będzie synekdochą, czyli rezultatem użyczenia fragmentowi - znaczeń całego zbioru.

Takie odwrócenia lub rozchwiania mogą być, jak twierdzi Ziomek, „rzeczą drugorzędną" - dla projektów klasyfikacyjnych retoryki, lecz mogą także niekiedy, jak choćby w obrazie „rozmowy dwóch krzeseł”, wpływać na interpretacje pojedynczych epizodów w przebiegach zdarzeń lirycznych, sprzyjać rozdwojonemu widzeniu, potęgując chwilową niepewność odbiorcy, która odgrywa w lekturze rolę równie doniosłą jak odbiorcza pewność. Sterowanie dramaturgią odbioru nie jest już zjawiskiem drugorzędnym. Natomiast kwestią wagi zgoła pierwszorzędnej staje się odmienność obu tropów, metonimii i synekdochy, w rekonstrukcjach takich poetyk autorskich, w których metonimie i synekdochy podejmują grę o dominantę, a przewaga jednej ze stron gry

11 Co pozwala niekiedy w słownikowych definicjach językoznawczych pomijać synekdochę, wyróżniając „częste [...] metonimie na zasadzie pars pro toto, tzn. nazwania części w miejsce całości”. Z. Gołąb, A. Heinz, K. Polański, Słownik terminologii językoznawczej, Warszawa 1968, s. 343.

12 Zob. M. Głowiński, T. Kostkiewiczowa, A. Okopień-Sławińska, J. Sławiński, Słownik terminów literackich, red. J. Sławiński, wydanie trzecie, poszerzone i poprawione, Wrocław 1998, s. 35.

13 W swej rekonstrukcji klasycznych systematyk metonimii i synekdochy Ziomek wyróżnia metonimię „patrona” (J. Ziomek, op.cit., s. 177), którą następnie omawia jako "synekdochę [...] zwaną antonomazją" (s. 178).

14 J. Ziomek, op.cit., s. 178. 
określa w danej poetyce - jej wizję świata ${ }^{15}$. Mam na myśli nie tyle drobne, kilkuwyrazowe odcinki wypowiedzi literackiej, zorganizowane według reguł metonimii lub synekdochy, ile przede wszystkim kompozycje literackie, pozwalające się odczytywać już to jako ,wielkie metonimie”, już to jako „wielkie synekdochy".

Dominacja metonimii oznacza, że świat przedstawiony w dziele poetyckim składa się z porządków osobnych i jednocześnie przyległych, graniczących $\mathrm{z}$ sobą tak trwale $\mathrm{i}$ tak ewidentnie, że możliwe jest między nimi wzajemne użyczanie znaczeń, co bynajmniej nie unieważnia dzielących je granic. Innymi słowy, oba zajmujące nas tropy mogą być rozpoznawane $\mathrm{i}$ traktowane nie tylko jako figury słowa i figury myśli, ale także - w szerszej perspektywie języka poetyckiego - jako figury mówienia i figury myślenia o świecie. Z punktu widzenia ontologii świat postrzegany metonimicznie odpowiada koncepcji dualistycznej, a szczególnie pluralistycznej. Przykładami ilustrującymi osobliwą , ,metonimiczność” światów przedstawianych/kreowanych przez artystów byłyby „wielość rzeczywistości” Leona Chwistka czy charakter czasoprzestrzeni w prozie homofonicznej Lwa Tołstoja (według Michaiła Bachtina). Z kolei kategoria synekdochy zakłada świat postrzegany jako skupisko zbiorów różnozakresowych oraz różnopoziomowych, które istnieją naprzemiennie jako podzbiory zbiorów mniejszych i nadzbiory zbiorów większych, a ich całość odpowiada założeniom ontologii monistycznej, tworząc - jak to określał Witkacy - ,jedność w wielości”. Swoistą, „dialogową” jednością $\mathrm{w}$ wielości odznacza się, jak utrzymywał Bachtin, powieściowa polifonia czasoprzestrzeni w Zbrodni i karze Fiodora Dostojewskiego. Podobnych opozycji między literackim nastawieniem na ontologiczny pluralizm lub monizm można wskazać więcej. W programach poetyckich XX wieku antynomia ta odzywa się w polemice krakowskiej awangardy z włoskim futuryzmem; bez wątpienia „słowa na wolności” Marinettiego powołują do życia osobliwy, anarchistyczny pluralizm, podczas gdy Peiperowa teoria sztuki zdominowanej przez składnię (budowę) zmierza w stronę ujęć monistycznych.

W poezji Wisławy Szymborskiej odnajdziemy zarówno metonimiczne, jak i synekdochiczne sposoby generowania poetyckich znaczeń. Czy któraś tendencja przeważa? Statystycznie uprawomocnioną odpowiedź na to pytanie należałoby poprzedzić szczegółową analizą wszystkich utworów Szymborskiej, uzgadniając - w miarę możliwości - analizę synchroniczną z ewolucjami jej stylu w poszczególnych okresach powojennych dziejów polskiej liryki. Brak tego typu analiz nie przekreśla przeświadczenia, że to nie metonimia, lecz

15 Powyższa teza nie jest próbą zakwestionowania, jest natomiast propozycją uszczegółowienia znanej dychotomii Jakobsona i Hallego, którzy utrzymywali, że w polaryzacji literackich dążeń należy brać pod uwagę (romantyczne) nastawienie na metaforę, traktowaną jako generator znaczeń - motywowany normą podobieństwa, i przeciwstawne jej (realistyczne) nastawienie na metonimię, odwołującą się do przyległości bytów. Zob. R. Jakobson, $W$ poszukiwaniu istoty języka, wybór, redakcja naukowa i wstęp M.R. Mayenowa, Warszawa 1989, s. 169-175. 
synekdocha w poezji autorki Jeszcze wyznacza mocny, wyrazisty nurt i wielokrotnie powołuje do istnienia podobny, choć zarazem urozmaicony, charakterystyczny dla poetki obraz świata.

\section{Odmiany synekdochy - odmiany świata}

Nastawienie na synekdochę w utworach autorki Chwili nie prowadzi do nieustannego powtarzania tych samych kombinacji językowych. Powtarzają się natomiast, w krótkich seriach, kombinacje różne, w niejednakowy sposób faworyzujące synekdochę, od całkowitego podporządkowania obrazu świata jej normom - do zastosowań i efektów epizodycznych. W porządku konstrukcyjnym, na poziomie signifiant, wyróżniają się następujące odmiany:

Wiersz zainicjowany przez synekdochę, która „upomina się" o własną rolę za pomocą parokrotnych powtórzeń, pozwalających niejako wznawiać, rozwijać lub ironicznie odwracać myśl główną. W Nieuwadze synekdochę typu totum pro parte tworzy „kosmos”, który powraca, jako obraz, w zdaniu: „Ziemia obróciła się na swojej osi”, lub, żartobliwie, w epitecie: „Kosmiczny savoir-vivre / Choć milczy na nasz temat / To jednak czegoś od nas się domaga" (s. 395-396). Podobną sytuację mamy w wierszu Bal. Problemem jego bohaterów jest „brak sygnałów, które by dobiegły” do Ziemi z innych planet, czyli - brak znaków typu pars pro toto (brak synekdoch). Mieszkańcy „niepozornego zaścianka” wszechświata czują się jedynymi istotami rozumnymi w uniwersum Bytu, gdyż nie otrzymują ,żadnych nowin / o lepszych lub gorszych gdzieś mozartach, / platonach czy edisonach" (s. 333). Cytowany passus mógłby zadowolić najbardziej wymagającego autora słownika tropów i figur - jako ilustracja jednej z odmian antonomazji, kiedy to imiona własne są przywołane dla oznaczenia „powszechnie znanej, szczególnie wyrazistej cechy”" a w konsekwencji zaczynają pełnić funkcję rzeczowników pospolitych ${ }^{17}$. Czytając o „mozartach, platonach, edisonach”, osobach „pomniejszonych” przez małe litery do ról bezosobowych, sprowadzonych do form nieczłowieczych, a zarazem zdolnych do wykonywania zadań kompozytorskich, filozoficznych tudzież wynalazczych, rozszerzamy granice kultury - o transgalaktyczną nieskończoność. W istocie bowiem ograniczenie postrzeganej rzeczywistości do jej wybranego wycinka nie kończy procesu oddziaływania synekdochy na odbiorcę. Rodzi reakcje polemiczne. Wskazanie Mozarta, Platona i Edisona znaczy na tle odrzuconych, acz prawdopodobnych alternatyw, w których przeważyłoby na przykład oczekiwanie „nowin / o lepszych lub gorszych gdzieś

16 J. Ziomek, op.cit., s. 178.

17 А. Квятковский, Поэтический словарь, Moskwa 1966, s. 44. Gry imienne w utworach Szymborskiej zwróciły uwagę znawców terminologii literackiej; Aleksandra Okopień-Sławińska przywołuje znane słowa z wiersza Wieczór autorski: „mieć wyrok skazujący na ciężkie norwidy” jako przykład „,antonomazji żartobliwej”. Zob. Słownik terminów literackich, s. 35. 
wagnerach, nietzschech czy oppenheimerach", albo myśl o spotkaniu w dalekim kosmosie „szymanowskich, ingardenów, skłodowskich-curie”. Na tym przykładzie widać założoną $\mathrm{w}$ analizowanym tropie, nieodzowną dla artyzmu sprzeczność między ograniczeniem horyzontu świata a sprowokowaną przez to ograniczenie transgresją.

Inną postacią $\mathrm{w}$ analizowanym kręgu jest wiersz zdominowany przez jeden, wciąż ten sam, w wielu wariantach powtarzany model synekdochy. Dzieje się tak w cytowanym i komentowanym na początku tego artykułu balladowym liryku Jeszcze, także w $A B C$, stanowiącym katalog osób znajomych - bezimiennych, ukrytych za inicjałami. „Nigdy już się nie dowiem, / co myślał o mnie A. / Czy B. do końca mi nie wybaczyła. / Dlaczego C. udawał, że wszystko w porządku. / Jaki był udział D. w milczeniu E.” (s. 369).

Zauważmy, że konsekwencją powtarzania różnych wersji tego samego modelu synekdochy musi być enumeracja, która w poezji Szymborskiej okazuje się najczęściej nagromadzeniem bytów przygodnych, rejestrowanych chaotycznie, w agresywnym nadmiarze, niedającym się opanować za pomocą żadnych procedur formalnych, choćby takich jak alfabet w wierszu $A B C$. Wyliczenie jednoczesnych, niepowstrzymanych, "ruchliwych szczegółów” (s. 395) osaczających ,ja” liryczne „ze wszystkich stron świata” (s. 183), „W zatrzęsieniu” przedmiotów i znaków (s. 330), w „terkocie interesów" (s. 347) itp. nadaje każdemu z fragmentów mniejszych lub większych całości status synekdochy. Każdy detal teraźniejszości, każdy ocalały szczątek minionego są bezcenne nie tylko ze względu na niepowtarzalność fenomenów Bytu, lecz także - paradoksalnie - na reprezentatywność w odniesieniu do różnych całości czy zbiorów, na przykład do umarłych kultur ( $A r$ cheologia, Muzeum, Grecki posag), zdarzeń onirycznych (Pochwała snów), niezidentyfikowanych tłumów i postaci (Jacyś), niedosłyszanych rozmów i kryjących się w nich ludzkich postaw, obyczajów, wrażliwości (Pogrzeb) czy jakichkolwiek innych alternatyw (Możliwości). Szczególna wartość takich drobin Bytu, ujętych w synekdochę, polega na tym, że - by uzupełnić ten wywód słowami poetki - jak starożytny grecki posąg, „, k którego zachował się tors", potrafią one

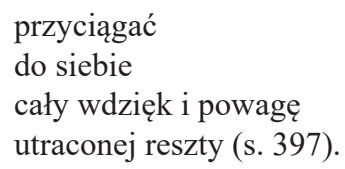

Przytoczony wyżej fragment prowadzi do jeszcze jednej grupy wierszy, zawierających refleksje na temat świata, który swoją organizacją wewnętrzną czyni synekdochę wiarygodnym, choć dalekim od doskonałości sposobem zdobywania w nim - o nim - informacji. Gdy w manifeście lirycznym ,późnej” Wisławy Szymborskiej czytamy:

Właściwie każdy wiersz mógłby mieć tytuł „Chwila” (s. 399) 
- mamy prawo pomyśleć, parafrazując cytowane słowa, że obcujemy z poezją, w której każda chwila, uchwycona w wierszu, mogłaby być synekdochą. Taką możliwość uzasadnia obraz świata, który w poezji Szymborskiej jest urządzony inkluzywnie, obejmujący lub łączący rozmaite zbiory w samosterującą się całość, świat będący jednością w wielości, przeznaczoną dla wszystkich bytów, z których każdy należy do jego licznych zasobów - jednocześnie. Obcość, a zwłaszcza wrogość między różnymi formami bytu i terytoriami świata, ludzi i zwierząt, zwierząt i roślin, kamieni i myśli, materii żywej i martwej, ma charakter umowny, ideologiczny, „nieszczelny”, a jeżeli „ludzki” - to jedynie w ironicznym, bolesnym wymiarze (s. 208).

Czy taki świat jest poznawalny? Odpowiedź twierdząca zostałaby bez trudu obalona przez liczne w poezji Szymborskiej paradoksy, interwencje ironii, świadectwa niepewności lub ostentacyjnej niewiedzy (s. 293). Ale odpowiedź przecząca podważałaby sens jej starań o zdefiniowanie fenomenów świata za pośrednictwem sentencji, utrwalenia jego chwil w lirycznych obserwacjach - operujących poetyką dosłowności lub dialogiem dosłowności z grą tropów, w tym z odmianami synekdoch. „Trudno osobę poznać po fragmentach”, czytamy w wierszu Sen starego żótwia (s. 212). Lecz „trudne” niekoniecznie musi znaczyć „niemożliwe”.

Poruszając się wśród śladów pewnych i niepewnych, symptomów prawdomównych i zdradliwych, podmiot liryczny poezji Szymborskiej postępuje tak, jak bohater jej Moralitetu leśnego:

Rodzaje, urodzaje widzi, rozpoznaje

wzajemne powiązania, związki, obowiązki,

zagmatwane początki, poplątane wątki,

a w zakątkach wyjątki (s. 372).

Ten sposób zdobywania orientacji przypomina zachowania ludzi nauki starej daty...

Jakiś czas temu w artykule zatytułowanym $W$ szkole świata napisałem pół żartem, pół serio, że zainteresowania realnością - postrzeganą naukowo - sytuują Szymborską w epoce - z ducha - pozytywistycznej, a jej poezja tę właśnie epokę - po latach - wzbogaca o dzieła niekłamanej urody. Poetka przysłała mi lapidarne i wymowne:

Panie Edwardzie, dzięki za eseik w „Tekstach”. Wyszło Panu, że jestem pozytywistką - niech będzie. Nie jest to - jak rozumiem - żaden wstyd?

Na odwrocie listu znajdowała się dowcipna wyklejanka: naga noga, obramowana ozdobnymi drzwiami szafy, z odręcznym wyjaśnieniem „,noga stolarza”. Obrazkowa ilustracja synekdochy podwojonej. Noga plus fragment szafy stanowiły czytelny dla każdego znak stolarstwa (synekdocha intersubiektywna). Dla mnie i mojej żony był to jednocześnie znak przedłużającego się remontu w domu Poetki, motywującego jej kolejny „nieprzyjazd” do Poznania (synekdocha towarzyska). 


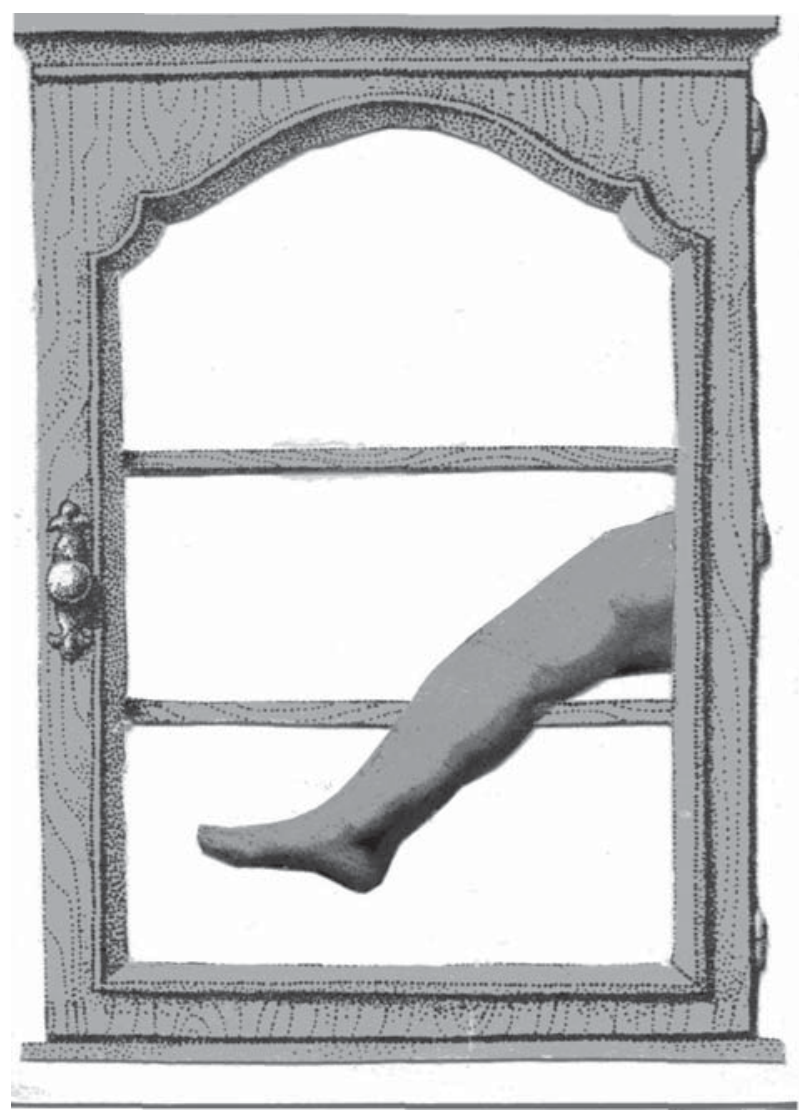

\section{Bibliografia}

Balcerzan E., Perspektywy „poetyki odbioru” [w:] Problemy socjologii literatury, red. J. Sławiński, Wrocław 1971.

Balcerzan E., Pochwała poezji. Z pamięci, z lektury, Mikołów 2013.

Dotykanie życia. Z Zofia Pociłowska-Kann rozmawia Dariusz Zaborek, „Wysokie Obcasy”, dodatek do „Gazety Wyborczej” z 10 września 2016, nr 37.

Głowiński M., Kostkiewiczowa T., Okopień-Sławińska A., Sławiński J., Słownik terminów literackich, red. J. Sławiński, wydanie trzecie, poszerzone i poprawione, Wrocław 1998.

Gołąb Z., Heinz A., Polański K., Stownik terminologii językoznawczej, Warszawa 1968.

Jakobson R., W poszukiwaniu istoty języka, wybór, redakcja naukowa i wstęp M.R. Mayenowa, Warszawa 1989.

Квятковский А., Поэтический словарь, Moskwa 1966. 
Okopień-Sławińska A., Metafora bez granic [w:] eadem, Semantyka wypowiedzi poetyckiej, Kraków 1998.

Przyboś J., Linia i gwar, t. 2, Kraków 1959.

Szymborska W., Wiersze wybrane, wybór i układ Autorki, wydanie nowe, uzupełnione, Kraków 2010.

Ziomek J., Retoryka opisowa, Wrocław 1990. 